\title{
ANALYSIS OF PSYCHOSOCIAL FACTORS OF THE PHARMACIST ADAPTATION TO THE PROFESSION
}

\author{
N.V.Teterych \\ National University of Pharmacy \\ Key words: socio-psychological factors; labour adaptation; pharmaceutical employees; \\ pharmaceutical activity; adaptive potential
}

The current activities of pharmaceutical employees are characterized by a significant increase in their functional responsibilities and require a high level of professionalism, initiative, perseverance and social competence determining the proper adaptation. The analysis of the literature on professional adaptation of pharmaceutical employees has shown that the study of resources of the adaptation process have not been assessed properly either in management psychology or in other disciplines related to it. According to the test results of pharmaceutical employees by the method of A.G.Maklakov and S.V.Chermyanin the basic factors of adaptability, namely the indicators of neuro-psychological stability, communicative ability and moral norms, as well as the final overall assessment of the personal adaptive potential have been determined. The results of the analysis conducted indicate the lack of nervous and mental stability of the respondents that poorly affects the course of their professional adaptation in pharmacies. The main areas to improve the level of professional adaptation of pharmaceutical employees are: assessment of the social and psychological competence; diagnostics of professional deformation; psychological trainings on the personal and professional growth for specialists; prevention of the occupational maladjustment of young professionals; mastering the skills of self-control of the emotional and volitional sphere and self-correction of professional deformations.

Currently, the main task of the psychology of management is to help employees to study and organise the professional activity by proper motivation and content, as well as contribute to its effective adaptation $[4,6,9]$. The professional activity of pharmaceutical employees is no exception; it is characterized by a significant increase in functional responsibilities and requires such professional and social-psychological criteria from specialists as a high level of professionalism that should be supported throughout the career, initiative, perseverance, and social competence $[1,3,4]$. The specialists' knowledge of their individual characteristics promotes fast mastering in the pharmaceutical profession and will provide further stability of the effective work and high professional achievements.

Thus, adaptation of a pharmaceutical employee in the professional activity is a complex, holistic process due to the combination of a number of socio-psychological and pedagogical factors that require theoretical under-standing and empirical study [1, 3, 4]. It should be remembered that professional development of pharmacists is a long process that starts from choosing the pharmaceutical profession to the first years of independent work in any sector of the pharmaceutical branch.

The analysis of the literature has shown that the abovementioned resources of the adaptation process are not evaluated properly either in the psychology of management that studies the set of processes of organizational behaviour of specialists or in other disciplines related to psychology [1, 5-10]. The management of this adaptation process is possible only on the basis of understanding of peculiarities and dynamics of the adap- tation mechanism of specialists to the professional activity. In this regard, the aim of the study was to analyse the social and psychological factors for adaptation of pharmacists to the professional activity and to identify the areas for its improvement.

\section{Materials and Methods}

To solve this problem a comprehensive testing of pharmaceutical employees that work in public and private pharmacies in various districts of Kharkov was conducted using the multi-personality questionnaire "Adaptability" by A.G.Maklakov and S.V.Chermyanin [2]. According to the recommendations of this method of the psychological research 30 questionnaires completed by respondents were taken into the study. In general, this method allows to determine the following parameters: neuro-psychological stability (NPS) - the integrated set of congenital and acquired personal qualities of specialists, their mobilization resources and reserve psychophysiological abilities that collectively provide the optimal performance in unfavourable conditions of the professional environment; the communicative ability (CA) - means and rules by which the employees can make the process of the effective communicative exchange with their opponents; the moral normativity (MN), which appropriate level provides the ability of the pharmacist to adequate perception of a relevant social role proposed for him/her [2].

The study identified and analysed the scores for each standardized test that reflect the level of professional adaptation. The total content of the standard assessment is determined as follows: credibility (C), NPS, CA, MN and the overall assessment of the results of the final 


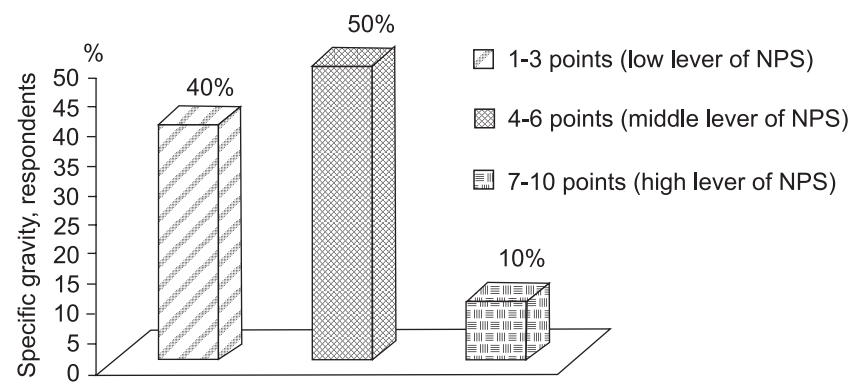

Fig. 1. Indicators of NPS of pharmaceutical employees according to A.G.Maklakov and S.V.Chermyanin.

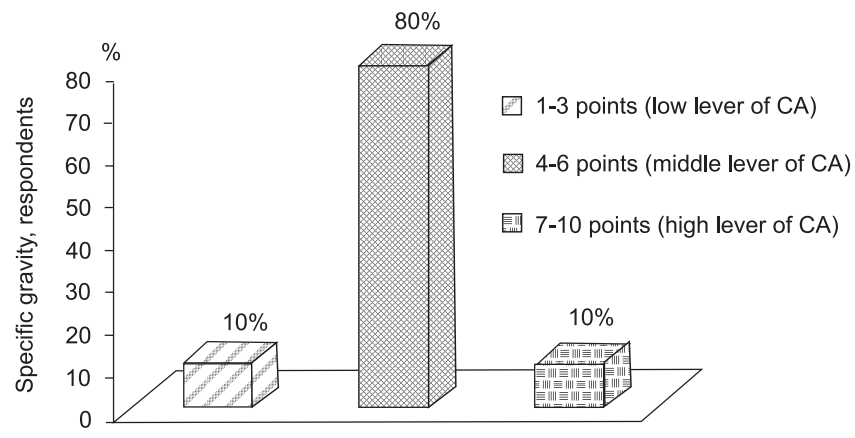

Fig. 2. The indicator of $C A$ of pharmaceutical employees according to A.G.Maklakov and S.V.Chermyanin.

scores of scales for NPS, CA and MN - personnel adaptive potential (PAP) [2].

The interpretation of these indicators is: 1-3 points the low level; 4-6 and 7-10 - the middle and high levels, respectively.

\section{Results and Discussion}

At the first stage of the study the NPS indicators were determined. The results are as follows: 12 respondents $(40 \%)$ have the low level of NPC, indicating a very low performance of behavioural regulation and susceptibility to neuro-mental breakdowns; half of respondents 15 professionals $(50 \%)$ have the middle level of behavioural regulation; the high indices of NPS indicating the neuro-psychic stability of the personality and the high level of regulation of behaviour and the adequate selfesteem were only in three professionals $(10 \%)$ (Fig. 1).

At the second stage of the study the CA indicator was determined. The results are as follows: only three professionals $(10 \%)$ have the low CA, which indicates the low level of their communicative abilities and is characterized by difficulties in contacting with others and the ability to express aggression; most specialists interviewed -24 respondents $(80 \%)$ have the middle level of CA indicating the satisfactory level of development of their communicative abilities, which meets the standards of constructive understanding between opponents; three pharmacists ( $10 \%$ of respondents) have the high CA index, which indicates the presence of the high level of communicativeness and makes it easy to contact with colleagues, physicians, visitors of pharmacies and others in public life and helps to find a constructive approach to resolving the conflict situation in case of occurrence (Fig. 2).

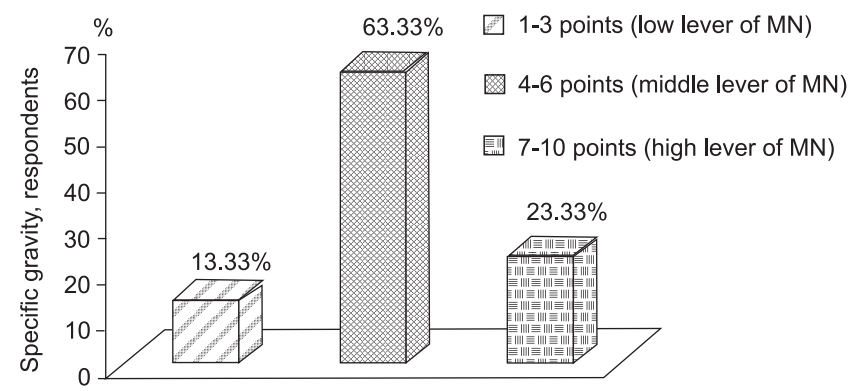

Fig. 3. The indicator of MN of pharmaceutical employees according to A.G.Maklakov and S.V.Chermyanin.

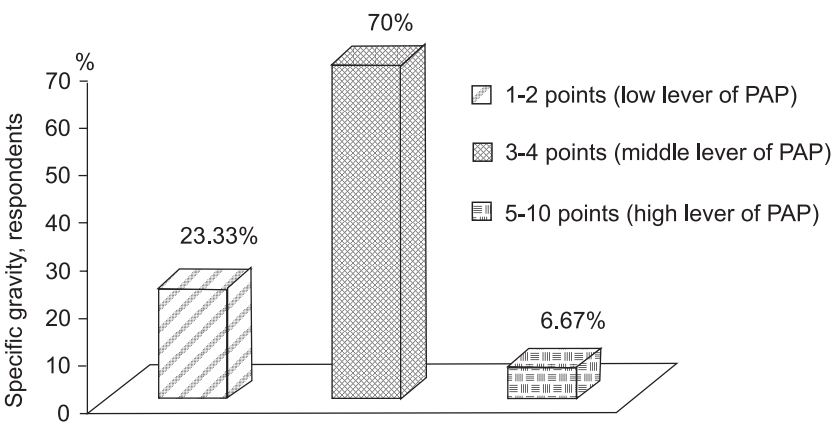

Fig. 4. Characteristics of the general level of PAP of the pharmaceutical employees according to A.G.Maklakov and S.V.Chermyanin.

The next - the third stage of the study included the analysis of the specialists' adaptability by the $\mathrm{MN}$ indicator. The results are as follows: four respondents $(13.33 \%)$ have the low $\mathrm{MN}$; it indicates understatement of the adequate assessment of their place and purpose in the team. The majority of respondents -19 professionals $(63.33 \%)$ received the middle level of $\mathrm{MN}$ indicating the adequate assessment of their role among the staff members. The high level of MN of 7 employees $(23.33 \%)$ indicates their conformity with the generally accepted norms of behaviour in the professional activity and understanding of the personal contribution to the work of the pharmacy (Fig. 3).

According to the research of pharmaceutical employees by this method and identification of NPS, CA and $\mathrm{MN}$ indicators the overall assessment of PAP was calculated and analysed.

Interpretation of PAP in terms of points is as follows: 1-2 points - the low level; 3-4 and 5-10 - the middle and high levels, respectively [2].

The results of PAP are as follows: almost a quarter of pharmacists - seven respondents $(23.33 \%)$ have the low level of PAP. These professionals have the low nervous and mental stability, capable of conflict situations and may act antisocially; the majority of respondents 21 respondents $(70 \%)$ received the middle level of the PAP index, indicating a satisfactory level of adaptation in the team. These professionals have an average level of emotional stability; it necessitates the application of an individual approach by management to them. Only two pharmaceutical employees $(6.67 \%)$ have the high indices of PAP, they are characterized as professionals who rather easily adapt to new conditions of the pro- 
fessional activity, quickly join the new staff members, relatively easily and adequately behave in any situation and quickly determine the strategy for their behaviour. These professionals have also the high emotional stability and are conflict-free.

The general characteristics of the PAP level of pharmacists according to A.G.Maklakov and S.V.Chermyanin method are given in Fig. 4.

Thus, the results of the analysis conducted indicate the lack of emotional or nervous and mental stability of the respondents that poorly affects the course of their professional adaptation in pharmacies. This indicates that these specialists have the certain professional deformations and require the professional adjustment by professional psychologists. The major areas to improve the professional adaptation of pharmaceutical employees should be: assessment of the social and psychological competence; diagnostics of professional deformation with further development of individual strategies for overcoming them; psychological trainings on the personal and professional growth for specialists; prevention of the occupational maladjustment of young professio- nals; mastering the skills of self-control of the emotional and volitional sphere and self-correction of professional deformations [4].

\section{CONCLUSIONS}

1. The analysis of the literature on professional adaptation of pharmaceutical employees has shown that the study of resources of the adaptation process have not been assessed properly either in the management psychology or in other disciplines related to it.

2. According to the test results of pharmaceutical employees by the method of A.G.Maklakov and S.V.Chermyanin the basic factors of adaptability, namely the indicators of neuro-psychological stability, communicative ability and moral norms, as well as the final overall assessment of the personal adaptive potential of professionals have been determined. The results of the analysis conducted indicate the lack of nervous and mental stability of the respondents that poorly affects the course of their professional adaptation in pharmacies.

3 . The main areas to improve the level of professional adaptation of pharmaceutical employees have been determined.

\title{
REFERENCES
}

1. Давтян Л.Л., Коритнюк Р.С. // Фармаи. кур’єр. - 2011. - №12. - С. 38-40.

2. Маклаков А.Г., Чермянина С.В. Многоуровневый личностный опросник «Адаптивность» (МЛО-АМ). [Електронний ресурс]. - Режим достуny: http://brunner.kgu.edu.ua/index.php/cv/69-adaptat.

3. Мнушко 3.М., Бондарєва I.В. // Управління, економіка та забезпечення якості в фармачії. - 2009. - №2. - C. 37-42.

4. Толочек В.А. Современная психол. труда. - С.Пб.: Питер, 2008. - 432 c.

5. Frishammar J. // Management Decision. - 2003. - Vol. 41, №4. - P. 318-326.

6. Hough J. // Management Decision. - 2004. - Vol. 42, №6. - P. 781-793.

7. Karim N. // Library Rev. - 2004. - Vol. 53, №7. - P. 356-362.

8. Velitchka D. // J. of Marketing. - 2006. - Vol. 70, №1. - P. 107-118.

9. Walsh P. // Management Decision. - 2005. - Vol. 43, №1. - P. 113-122.

10. Yunggar M. // J. of American Academy of Business, Cambridge. - 2005. - Vol. 6, №2. - P. 324-331.

\begin{abstract}
АНАЛІЗ СОЦІАЛЬНО-ПСИХОЛОГІЧНИХ ФАКТОРІВ АДАПТАЦІЇ ФАРМАЦЕВТИЧНИХ ПРАЦІВНИКІВ ДО ПРОФЕСІЙНОЇ ДІЯЛЬНОСТІ

H.B.Tетерич

Ключові слова: соціально-психологічні фрактори; трудова адаптація; фрармацевтичні працівники; фрармацевтична діяльність; адаптивний потенціал Сучасна діяльність фрармацевтичних працівників характеризується значним підвищенням їх ффункціональних обов'язків та вимагає наявності високого рівня професіоналізму, ініціативності, наполегливості і соціальної компетентності, що зумовлює їх належну адаптацію. Аналіз літературних джерел з питань адаптації до профресійної діяльності фрармацевтичних працівників показав, що вивчення ресурсів процесу адаптації не оцінюється належним чином ні у психології менеджменту, ні в інших сумісних з нею дисциплінах. За результатами тестування фрармацевтичних працівників за методикою А.Г.Маклакова та С.В.Чермяніна визначені основні чинники їх адаптивності, а саме: рівні нервово-психологічної стійкості, комунікативної здатності та моральної нормативності, а також підсумкова загальна оцінка особистісного адаптивного потенціалу. Результати проведеного аналізу свідчать про нестачу нервово-психічної стійкості респондентів в аптеках, що незадовільно позначається на процесі їх профресійної адаптації. Виділені основні напрямки щодо підвищення рівня профресійної адаптації фрармацевтичних працівників: оцінка рівня соціально-психологічної компетентності; діагностика професійних деформацій; проходження фрахівиями психологічних тренінгів щодо особистісного та профресійного зростання; запобігання профресійній дезадаптації молодих фрахівців; оволодіння навичками саморегуляції емоційно-вольової сфрери та самокорекції профресійних деформацій.
\end{abstract}




\section{АНАЛИЗ СОЦИАЛЬНО-ПСИХОЛОГИЧЕСКИХ ФАКТОРОВ АДАПТАЦИИ ФАРМАЦЕВТИЧЕСКИХ РАБОТНИКОВ К ПРОФЕССИОНАЛЬНОЙ ДЕЯТЕЛЬНОСТИ} H.B.Temepuч

Ключевые слова: социально-психологические фракторы; трудовая адаптация;

фрармацевтические работники; фрармацевтическая деятельность; адаптивный потенциал Современная деятельность фрармацевтических работников характеризуется значительным повышением круга их функциональных обязанностей и требует наличия высокого уровня профрессионализма, инициативности, настойчивости и социальной компетентности, которая предопределяет их надлежащую адаптацию. Анализ литературных источников по вопросам адаптации фрармацевтических работников к профрессиональной деятельности показал, что изучение ресурсов процесса адаптации не оценивается должным образом ни в психологии менеджмента, ни в других совместимых с ней дисциплинах. По результатам тестирования фрармацевтических работников по методике А.Г.Маклакова и С.В.Чермянина определены основные факторы их адаптивности, а именно: показатели нервно-психологической устойчивости, коммуникативной способности и моральной нормативности, а также итоговая общая оценка личностного адаптивного потенциала. Результаты проведенного анализа свидетельствуют о недостатке уровня нервно-психической стойкости испытуемых, что неудовлетворительно отражается на процессе их профеессиональной адаптации. Выделены основные направления по повышению уровня профрессиональной адаптации фармацевтических работников: оценка уровня социально-психологической компетентности; диагностика профессиональных деформаций; прохождение специалистами психологических тренингов относительно личностного и професссионального роста; предотвращение профессиональной дезадаптации молодых фрармацевтических специалистов; овладение навыками саморегулирования эмоционально-волевой сферы и самокоррекции профессиональных деформаций. 